WSRC-TR-90-245

\title{
Radioactive Effluents in the Savannah River: Summary Report for 1989 (U)
}

W. G. Winn

Westinghouse Savannah River Company

Savannah River Site

Aiken, SC 29808

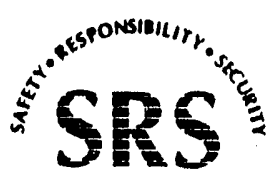

SAVANNAH RIVER SITE

Prepared for the U. S. Department of Energy under contract no. DE-AC09-89SR18035 


\section{Disclaimer}

This report was prepared as an account of work sponsored by an agency of the United States Government. Neither the Uniizd States Government nor any agency thereof, nor any of their employees, makes any warraniy, express or implied, or assumes any legal liability or responsibility for the accuracy, completeness, or usefulness of any information, apparatus, product, or process disclosed, or represents that its use would not infringe privately owned rights. Reference herein to any specific commercial product, process, or service by trade name, trademark, manufacturer, or otherwise does not necessarily constitute or imply its endorsemeni, recommendation, or favoring by the United States Government or any agency thereof. The views and opinic as of authors expressed herein do not necessarily state or reflect those of the United States Government or any agency thereof.

Printed in the United States of America

Available From

National Technical Information Service

U. S. Department of Commerce

5285 Port Royal Road

Springfield, Virginia 22161

Price: Printed Copy A03, Microfiche A01 
WSRC-TR-90-245

Distribution Category: UC 702

WSRC-TR- $-90-245$

DE92 007229

\section{Radioactive Effluents in the Savannah River: Summary Report for 1989}

Prepared by: W. G. Winn

Publication Date: September 1991

Westinghouse Savannah, River Company

Savannah River Site

Aiken. South Carolina 29808

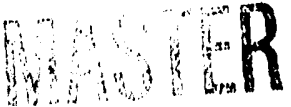

Prepared for the U. S. Department of Energy under contract no. DE-AC09-89SR 18035 


\title{
Contents
}

\author{
Abstract 1 \\ Introduction 1 \\ Discussion 1 \\ River Sampling 1 \\ Laboratory Measurements 2 \\ Underwater Nal(TI) Measurements 2 \\ Results 2
}

Conclusions 2

Summary 9

Acknowledgments 10

References 10 


\section{List of Figures}

1. ${ }^{58} \mathrm{Co}$ in the Savannah River in 1989) 3

2. ${ }^{60} \mathrm{Co}$ in the Savannah River in 19894

3. ${ }^{137} \mathrm{Cs}$ in the Savannah River in $1989 \quad 5$

4. Results for Underwater Nal Detector at the Highway 301 Bridge 8

5. Results of Underwater $\mathrm{Nal}{ }^{58} \mathrm{Co}$ (1989) 9

6. Results of Resin Samples for ${ }^{58} \mathrm{Co}$ at Highway 301 Bridge (1989) 9

\section{List of Tables}

1. ${ }^{58} \mathrm{Co}$ Concentrations in $1989 \quad 3$

2. ${ }^{60} \mathrm{Co}$ Concentrations in $1989 \quad 4$

3. ${ }^{137}$ Co Concentrations in $1989 \quad 5$

4. Relative Isotopics Below Vogtle During 19896

5. Tritium Concentrations in 19897

6. Sediment Concentrations in 19897

7. Comparison of Maximum 1989 Levels with DOE Guides for Drinking Water 10 


\title{
Radioactive Effluents in the Savannah River- Summary Report for 1989 (U)
}

\author{
By W. G. Winn \\ Westinghouse Savannah River Company \\ Savannah River Site \\ Aiken, SC 29808
}

\begin{abstract}
Researchers at the Savannah River Site have low-level radiometric studies of the Savannah River to distinguish between the effluent contributions of the Savannah River Site and Plant Vogtle. Since the startup of Plant Vogtle in 1987, researchers have routinely detected neutron-activated isotopes in controlled releases, but all have been well below the Department of Energy's (DOE) guidelines. The study has found that processing improvement at Plant Vogtle during 1989 have lowered the activities of effluents from Plant Vogtle. These studies will continue on a routine basis because they provide disturbing trends before actual health concerns evolve.
\end{abstract}

\section{Introduction}

During 1989 low-level radiometric studies of the Savannah River continued to distinguish between effluent contributions from Plant Vog!le and the Savannah River Site. Both institutions have interest in the measurements of the radioactive effluents. Analysis of the data helps the institutions address disturbing trends before they become health and legal concerns.

The Environmental Technology Section (ETS) conducted radiometric studies of Plant Vogtle (since late 1986) prior to its startup.' The plant has two $1100 \mathrm{MWe}$ pressurized water reactors developed by Westinghouse: Unit 1 started commercial operations in June 1987, and Unit 2 followed in May 1989. During powered operations ETS routinely detected neutron-activated isotopes in controlled releases, but all activities have been several orders of magnitude below the DOE guide values. ${ }^{2.3 .4}$ Processing improvements in 1989 lowered the activities of Vogtle effluents in the river. The Plant Vogtle release data and the ETS measurements correlated well from 1987-1989.

Researchers measure effluents by using ETS ultralow-level radiometric measurement techniques. The techniques generally include concentrating river samples on resins, preparing them in the lab, and then counting the effluents in the underground counting facility in 735-A. ${ }^{3}$ Researchers use gamma spectrometry for most of the counting and liquidscintillation counting for tritium. Gamma-ray analysis provides detection limits that are thousands of times lower than those routinely achievable. (Tritium analysis also uses stateof-the-art detection sensitivity.) An underwater $\mathrm{NaI}(\mathrm{T})$ ) at
Highway 301 bridge provides continuous gamma monitoring of the Savannah River.

\section{Discussion}

During 1989 observers found noticeably less radioactive effluents in the Savannah River than in 1987-1988. This observation correlates with improvements made at Vogtle for processing liquid effluents. The Vogtle effluents continue to be dominated by ${ }^{38} \mathrm{Co}$, which had a maximum concentration of $3.9 \mathrm{pCi} / \mathrm{L}$ at the beginning of 1989 , but stayed below $0.6 \mathrm{pCi} / \mathrm{L}$ after February. Observers found trace amounts of ${ }^{31} \mathrm{Cr},{ }^{34} \mathrm{Mn},{ }^{37} \mathrm{Co},{ }^{39} \mathrm{Fe},{ }^{80} \mathrm{Co},{ }^{95} \mathrm{Nb}$, and ${ }^{95} \mathrm{Zr}$ in the effluents; similar observations were made in 1987 and 1988. Monitoring of tritium and ${ }^{137} \mathrm{Cs}$ found their levels consistent with known SRS sources.

\section{River Sampling}

Researchers collected samples from the Savannah River at Shell Bluff, areas near the Vogtle outfall, and by the Highway 301 Bridge. Effluents from Vogtle and SRS cause the increase in activity from Shell Blut to the Highway 301 bridge. Measurements upstream and downstream of the Vogtle outfall $(0.3 \mathrm{mi}$ above, $0.1 \mathrm{mi}$ below, and at the Vogtle outfall) identify Vogtle contributions.

Three types of samples were collected-resin, water, and sediment. Resin-concentrator samples, which consist of approxinately $25 \mathrm{~g}$ of resin in a porous nylon bag, stay in the water for two weeks before being returned to the lab. Researchers directly collect water samples. A specially 
designed sampler that is pulled along the bortin of the river scoops sediment samples. The Vogtle prestartup study details the sampling methods.'

\section{Laboratory Measurements}

The resir concentrator samples provide the most comprehensive isotopic information. Technicians dried and turned each sample into ash to achieve a smaller volume and better geometry for the high-purity germanium detector (HPGe) detector. Typically, two HPGe detectors, which have ${ }^{60} \mathrm{Co}$ standard efficiencies of $20 \%$ and $25 \%$, counted the samples. (A new detector, with a ${ }^{\omega} \mathrm{Co}$ standard efficiency of $90 \%$, analyzed special cases.) Analysts processed the samples overnight (or over the weekend) to assure good counting statistics for detecting low-level activities. An IBM/PC-XT used the GRABGAM code to analyze the resulting HPGe gamma-ray spectra to yield the activity ( $\mathrm{fCi}$ ) of each isotope detected in the resin sample. ${ }^{5}$ By using empirical calibration data that relate the resin mass and collection time to the effective water volume (L), analysts obtained the average isotopic concentration ( $\mathrm{fCi} / \mathrm{L}$ ) for the collection period.

A TRICARB LL 2050A low-level liquid scintillation analyzer examined samples with $3 \mathrm{~mL}$ of water and $20 \mathrm{~mL}$ of OPTI-FLUOR ${ }^{\mathrm{TM}}$ scintillant for tritium. Duplicate samples with $0.25 \mathrm{~mL}$ of tritium standard checked the performance of the automatic quench corrections.

Sediment samples were transferred to 1-L Marinelli beakers and then counted on the HPGe detectors. Analysts divided the sample isotopic activities ( $\mathrm{fCi}$ ) from the gamma-ray analysis by the dry weight $(\mathrm{g})$ of each sample to yield the corresponding concentrations ( $\mathrm{fCi} / \mathrm{g}$ ).

\section{Underwater $\mathrm{Nal}(\mathrm{Tl})$ Measurements}

The underwater $\mathrm{Nal}(\mathrm{Tl})$ detector operates from a stationary pontoon boat near the Highway 301 bridge. The detector includes a 9 in. diameter by $4 \mathrm{in.}$ long $\mathrm{NaI}(\mathrm{Tl})$ detector, four photo-multiplier tubes, and a high-voltage/preamp unit; everythir $\mathrm{g}$ is contained in a waterproof stainless steel housing. The detector views its surroundings through a thin hemispherical dome.

The detector receives operating power through a waterproof cable connected to a $\approx 25 \mathrm{~V}$ DC supply in the cabin of the pontoon boat. A unit within the detector assembly boosts this voltage to about $1000 \mathrm{~V}$ for photo-tube operation. The same cable transmits the AC-coupled detector signals to the cabin. where they are amplified and sent to a multichannel analyzer.
A multichannel analyzer, which is comprised of a COMPAQ 286 computer and an ACE MCA card from EG\&G ORTEC, collects spectral data.. Spectra are stored on a floppy disk in sequenced 24hr periods for two to three weeks until researchers retrieve the disk and analyze it at the laboratory. This detector system provides better time resolution (one day) than the resin concentrator method (two weeks), but its sensitivity is one order of magnitude less. ${ }^{3}$

\section{Results}

This section summarizes the measurement results and comments briefly on their significance. The next section (Discussion) provides a more detailed account.

The resin sampler analysis continued to indicate ${ }^{58} \mathrm{Co},{ }^{60} \mathrm{Co}$, and ${ }^{137} \mathrm{Cs}$, which were the most significant gamma-emitting radionuclides detected in the earlier studies. ${ }^{1.33}$ The 1989 results for these isotopes are given in tables 1-3, along with plots in figures 1-3. The other detected man-made radionuclides correlate with ${ }^{58} \mathrm{Co}$ and are included in Table 4. The activities are the lowest observed since the Vogtle startup in 1987.

Water analysis for tritium followed techniques used earlier. ${ }^{12}$ Table 5 summarizes the 1989 tritium results. These low-tritium levels have essentially not changed over the past few years.

Sediments were analyzed for ${ }^{98} \mathrm{Co},{ }^{60} \mathrm{Co}$, and ${ }^{137} \mathrm{Cs}$ to appraise whether any deposition is occurring during the transport of these isotopes in river water. The corresponding results (see Table 6) show that only very low levels of those man-made radionuclides continue to be observed.

Figure 4 presents an isometric plot of count rate vs gamma energy and date from the data collected by the underwater $\mathrm{Nal}(\mathrm{Tl})$ detector. Figures 5 and 6 compare the ${ }^{58} \mathrm{Co}$ detected by the underwater $\mathrm{NaI}(\mathrm{Tl})$ with that detected with the resin concentrator samples. The two methods continue to correlate well.

\section{Conclusions}

In 1989 overall man-made radioactivity in the Savannah River was significantly lower than in the preceding year. This was primarily due to improvements in Plant Vogtle processing of effluent waste. River water samples show that Vogtle effluents continue to contain ${ }^{51} \mathrm{Cr},{ }^{54} \mathrm{Mn},{ }^{37} \mathrm{Co},{ }^{34} \mathrm{Co}$, ${ }^{59} \mathrm{Fe},{ }^{95} \mathrm{Nb}$ and ${ }^{95} \mathrm{Zr}$. Aside from these Vogtle contributions, the other activities remained consistent with levels of SRS radionuclides ${ }^{3} \mathrm{H},{ }^{60} \mathrm{Co}$, and ${ }^{137} \mathrm{Cs}$ detected prior to Vogtle 
Table 1. ${ }^{58} \mathrm{Co}$ Concentrations in $1989($ Values in $\mathrm{fCi} / \mathrm{L})$

\begin{tabular}{|c|c|c|c|c|}
\hline Date & $\begin{array}{c}\text { Shell Bluff } \\
\mathrm{fCl} / \mathrm{L}\end{array}$ & $\begin{array}{c}\text { Above Vogtle } \\
\mathrm{fCl} / \mathrm{L}\end{array}$ & $\begin{array}{l}\text { Below Vogtle } \\
\mathrm{fCl} / \mathrm{L}\end{array}$ & $\begin{array}{c}\text { H301 Bridge } \\
\mathrm{fCl} / \mathrm{L}\end{array}$ \\
\hline $12 / 14 / 88-1 / 5 / 89$ & $-2,48$ & -1.96 & 3897.07 & 443.40 \\
\hline $1 / 5-1 / 19 / 89$ & -2.55 & -2.65 & 2113.70 & 40.22 \\
\hline $1 / 19 \cdot 2 / 2 / 89$ & -3.38 & -2.85 & 1099.72 & 69.64 \\
\hline $2 / 2 \cdot 2 / 16 / 89$ & -2.49 & -1.97 & 377.67 & 33.80 \\
\hline $2 / 16 \cdot 3 / 2 / 89$ & -4.24 & -5.77 & 505.16 & 51.12 \\
\hline $3 / 2 \cdot 3 / 16 / 89$ & -2.80 & -9.46 & 176.61 & 30.71 \\
\hline $3 / 16 \cdot 3 / 30 / 89$ & -6.65 & -9.49 & 121.79 & 20.79 \\
\hline $3 / 30-4 / 13 / 89$ & -7.01 & -9.91 & 98.91 & 22.78 \\
\hline $4 / 13 \cdot 4 / 27 / 89$ & -3.88 & -7.59 & 82.53 & 5.78 \\
\hline $4 / 27 \cdot 5 / 11 / 89$ & -4.63 & -3.58 & 29.37 & -3.53 \\
\hline $5 / 11-5 / 25 / 89$ & -3.87 & -5.85 & 143.15 & -5.82 \\
\hline $5 / 25 \cdot 6 / 08 / 89$ & -5.51 & na & 246.54 & 8.07 \\
\hline $6 / 08-6 / 22 / 89$ & na & -5.25 & 31.44 & 8.88 \\
\hline $6 / 22-7 / 6 / 89$ & -6.92 & -7.05 & 24.50 & -6.85 \\
\hline $7 / 6-7 / 20 / 89$ & -5.75 & -6.20 & 124.14 & 8.85 \\
\hline $7 / 20-8 / 3 / 89$ & -5.48 & -5.02 & 50.68 & -5.41 \\
\hline $8 / 3-8 / 17 / 89$ & -3.29 & -5.45 & 171.97 & 7.12 \\
\hline $8 / 17-8 / 31 / 89$ & -4.92 & -4.41 & 91.99 & 39.23 \\
\hline $8 / 31 \cdot 9 / 14 / 89$ & -4.74 & -3.56 & 180.23 & 12.44 \\
\hline $9 / 14$ - 9/28/89 & -4.09 & -5.36 & 107.69 & 3.34 \\
\hline $9 / 28-10 / 12 / 89$ & -3.95 & 4.69 & 121.87 & 6.50 \\
\hline $10 / 12 \cdot 10 / 26 / 89$ & -10.28 & -18.13 & 540.51 & 17.50 \\
\hline $10 / 26 \cdot 11 / 09 / 89$ & -5.19 & -5.61 & 755.61 & 15.63 \\
\hline $11 / 09-11 / 22 / 89$ & na & -5.03 & 422.52 & 163.47 \\
\hline $11 / 22-12 / 07 / 89$ & -4.11 & -4.71 & 299.10 & 16.92 \\
\hline $12 / 07-12 / 21 / 89$ & -9.91 & -7.26 & 35.59 & -9.78 \\
\hline $12 / 21 / 89.01 / 04 / 90$ & -5.26 & -6.29 & 20.40 & -9.07 \\
\hline
\end{tabular}

a) Counting error estimated at $\leq 0.82 \sqrt{V}$ where $V$ is entry value. Values with minus (-) are minimum detectable values

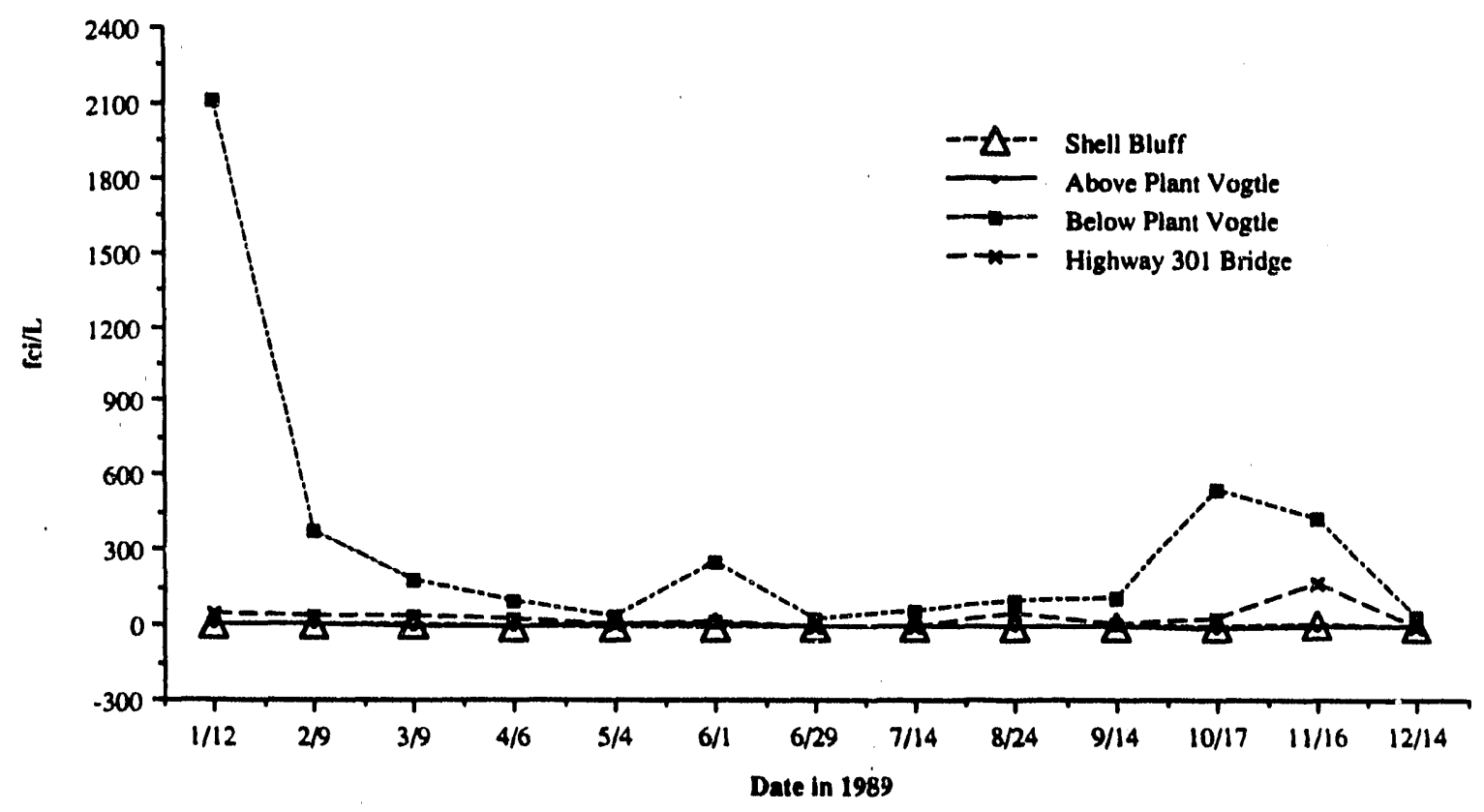

Figure 1. ${ }^{58} \mathrm{Co}$ in the Savannah River in 1989 [Negative Values are Minimum Detectable Amounts (MDAs)] 
Table 2. ${ }^{60} \mathrm{Co}$ Concentrations in 1989 (Values in $\left.\mathrm{fCi} / \mathrm{L}\right)^{2}$

\begin{tabular}{|l|cccc|}
\hline \multicolumn{1}{|c|}{ Date } & $\begin{array}{c}\text { Shell Bluff } \\
\text { fCi/L. }\end{array}$ & $\begin{array}{c}\text { Above Vogtle } \\
\text { fCi/L }\end{array}$ & $\begin{array}{c}\text { Below Vogtle } \\
\text { fCi/L }\end{array}$ & $\begin{array}{c}\text { H301 Bridge } \\
\text { fCi/L }\end{array}$ \\
\hline $12 / 14-1 / 5 / 89$ & & & & \\
$1 / 5-1 / 19$ & -2.00 & -1.60 & 225.50 & 46.90 \\
$1 / 19-2 / 2$ & -2.40 & -2.40 & 94.10 & 5.90 \\
$2 / 2-2 / 16$ & -3.30 & -2.70 & 93.10 & 8.60 \\
$2 / 16-3 / 2$ & -2.40 & -1.90 & 59.10 & 8.40 \\
$3 / 2-3 / 16$ & -3.40 & -4.70 & 47.40 & 9.30 \\
$3 / 16-3 / 30$ & -2.50 & -8.50 & 49.60 & 7.40 \\
$3 / 30-4 / 13$ & -5.00 & -8.00 & 37.50 & 13.50 \\
$4 / 13-4 / 27$ & -5.60 & -7.40 & 13.50 & -5.70 \\
$4 / 27-5 / 11$ & -3.50 & -6.60 & 30.00 & -3.30 \\
$5 / 11-25$ & -3.70 & -2.80 & 13.70 & -3.50 \\
$5 / 25-6 / 08$ & -3.70 & -4.90 & 45.30 & -4.80 \\
$6 / 08-22$ & -6.40 & $n a$ & 63.10 & -4.40 \\
$6 / 22-7 / 6$ & $n a$ & -4.50 & 14.90 & 4.80 \\
$7 / 6-20 / 89$ & -6.10 & -6.20 & 20.70 & -6.40 \\
$7 / 20-8 / 3 / 89$ & -5.40 & -5.20 & 25.30 & 8.30 \\
$8 / 3-8 / 17 / 89$ & -4.80 & -4.80 & 8.20 & -5.10 \\
$8 / 17-31 / 89$ & -3.00 & -4.90 & 44.70 & 11.20 \\
$8 / 31-9 / 14 / 89$ & -4.70 & -4.40 & 35.60 & 7.80 \\
$9 / 14-9 / 28 / 89$ & -4.10 & -3.00 & 95.70 & 8.80 \\
$9 / 28-10 / 12 / 89$ & -5.00 & -4.90 & 31.30 & -3.00 \\
$10 / 12-10 / 26 / 89$ & -3.60 & -7.50 & 10.20 & -4.50 \\
$10 / 26-11 / 09 / 89$ & -5.10 & -9.60 & 88.70 & 6.20 \\
$11 / 09-11 / 22 / 89$ & -3.50 & -3.40 & 44.70 & -7.20 \\
$11 / 22-12 / 07 / 89$ & -2 & -3.10 & 21.30 & 7.50 \\
$12 / 07-12 / 21 / 89$ & -2.60 & -3.00 & 49.60 & 7.60 \\
$12 / 21-01 / 04 / 90$ & -7.30 & -5.50 & -10.00 & -6.50 \\
& -3.20 & -8.60 & -6.20 & -5.90 \\
\hline
\end{tabular}

a) Counting error estimated at $\leq 0.75 \sqrt{V}$ where $V$ is entry value. Values with minus (-) are minimum detectable values

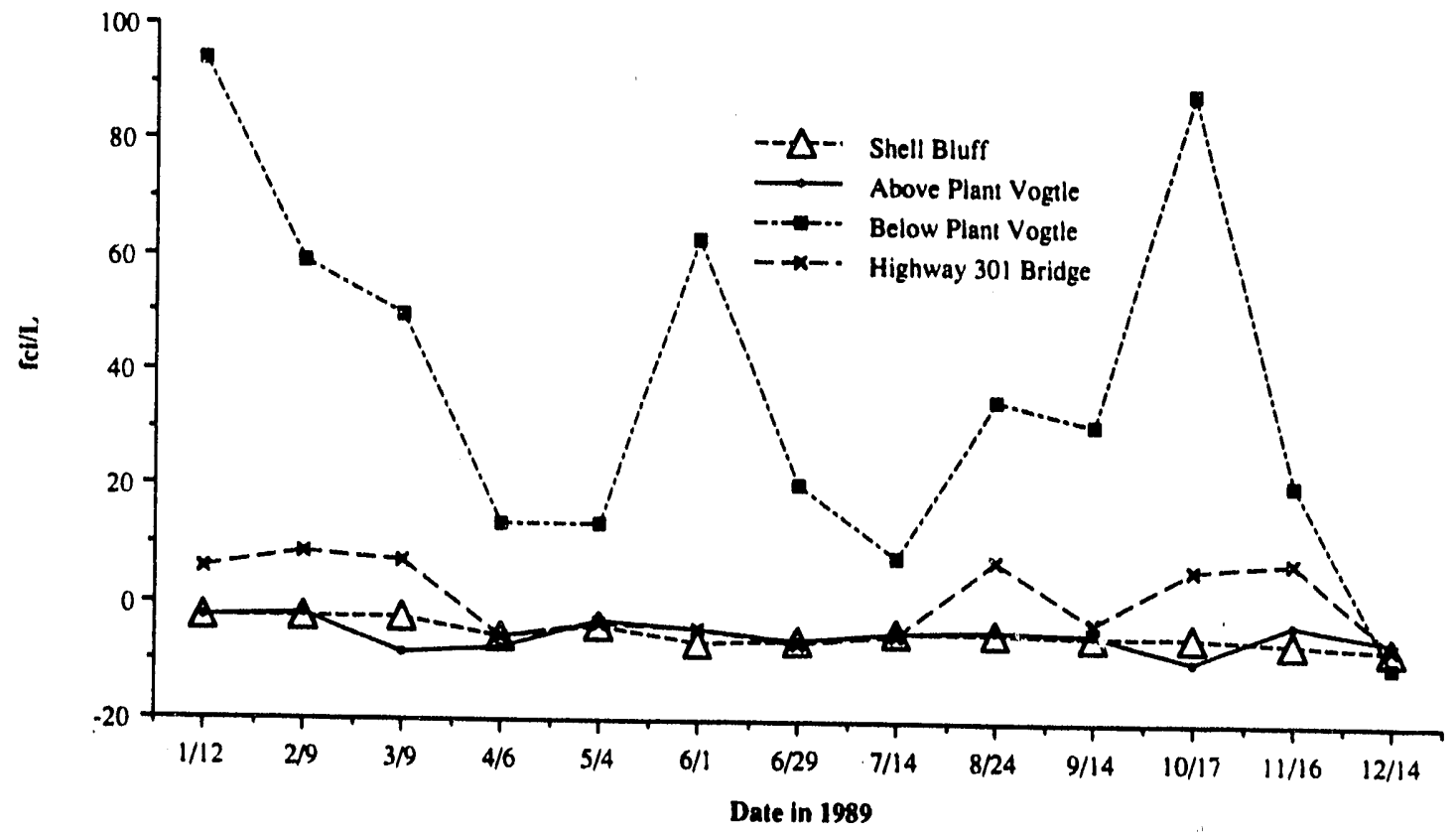

Figure 2. ${ }^{60} \mathrm{Co}$ in the Savannah River in 1989 (Negative Values are MDAs) 
Table 3. ${ }^{137} \mathrm{Co}$ Concentrations in $1989(\text { Values in } \mathrm{fCl} / \mathrm{L})^{2}$

\begin{tabular}{|c|c|c|c|c|}
\hline Date & $\begin{array}{c}\text { Shell Bluff } \\
\mathrm{FCI} / \mathrm{L}\end{array}$ & $\begin{array}{c}\text { Above Vogtle } \\
\mathrm{fCi} / \mathrm{L}\end{array}$ & $\begin{array}{c}\text { Below Vogtle } \\
\mathrm{KCi} / \mathrm{L}\end{array}$ & $\begin{array}{c}\text { H301 Bridge } \\
\mathrm{fCi} / \mathrm{L}\end{array}$ \\
\hline $12 / 14 / 88-1 / 5 / 89$ & .3 .10 & 4.45 & 11.86 & 56.44 \\
\hline $1 / 5-1 / 19 / 89$ & 2.28 & 2.30 & 11.62 & 19.83 \\
\hline $1 / 19-2 / 2 / 89$ & 5.06 & 3.38 & 4.05 & 34.09 \\
\hline $2 / 2 \cdot 2 / 16 / 89$ & 3.60 & 6.37 & 3.41 & 30.61 \\
\hline $2 / 16-3 / 2 / 89$ & 8.37 & 11.35 & 10.99 & 37.13 \\
\hline $3 / 2 \cdot 3 / 16 / 89$ & 5.77 & 11.36 & 13.26 & 77.54 \\
\hline $3 / 16-3 / 30 / 89$ & 8.45 & 15.66 & 18.33 & 36.15 \\
\hline $3 / 30-4 / 13 / 89$ & 7.12 & 11.68 & 16.26 & 46.92 \\
\hline $4 / 13-4 / 27 / 89$ & 7.23 & 11.63 & 17.51 & 26.52 \\
\hline $4 / 27 \cdot 5 / 11 / 89$ & 6.45 & 6.80 & 13.01 & 30.35 \\
\hline $5 / 11-5 / 25 / 89$ & 5.52 & 17.13 & 23.43 & 30.52 \\
\hline $5 / 25-6 / 08 / 89$ & 6.59 & $\mathrm{na}$ & 14.54 & 51.89 \\
\hline $6 / 08-6 / 22 / 89$ & na & 11.12 & 8.45 & 46.44 \\
\hline $6 / 22 \cdot 7 / 6 / 89$ & 14.78 & 20.18 & 29.16 & 66.65 \\
\hline $7 / 6 \cdot 7 / 20 / 89$ & 12.65 & 25.25 & 40.20 & 118.79 \\
\hline $7 / 20-8 / 3 / 89$ & 7.90 & 15.96 & 22.53 & 47.80 \\
\hline $8 / 3-8 / 17 / 89$ & 9.61 & 13.32 & 13.71 & 46.30 \\
\hline $8 / 17-8 / 31 / 89$ & 9.54 & 6.31 & 11.30 & 51.04 \\
\hline $8 / 31 \cdot 9 / 14 / 89$ & 4.91 & 9.31 & 8.81 & 34.45 \\
\hline $9 / 14 \cdot 9 / 28 / 89$ & 6.82 & 9.87 & 19.47 & 23.84 \\
\hline $9 / 28-10 / 12 / 89$ & 3.03 & 14.39 & 7.94 & 31.87 \\
\hline $10 / 12-10 / 26 / 89$ & 8.74 & 14.00 & 12.90 & 27.66 \\
\hline $10 / 26-11 / 09 / 89$ & 5.25 & 4.17 & 7.91 & 50.61 \\
\hline $11 / 29-11 / 22 / 89$ & na & 2.31 & 8.62 & 33.36 \\
\hline $11 / 22 \cdot 12 / 07 / 89$ & 2.82 & 7.10 & 13.25 & 26.06 \\
\hline $12 / 07-12 / 21 / 89$ & 11,42 & -3.71 & 13.38 & 23.55 \\
\hline $12 / 21 / 89-01 / 04 / 90$ & 5.25 & 4.39 & 10.32 & 32.72 \\
\hline
\end{tabular}

a) Counting error estimated at $\leq 0.75 \sqrt{V}$ where $V$ is entry value. Values with minus (-) are minimum detectable values

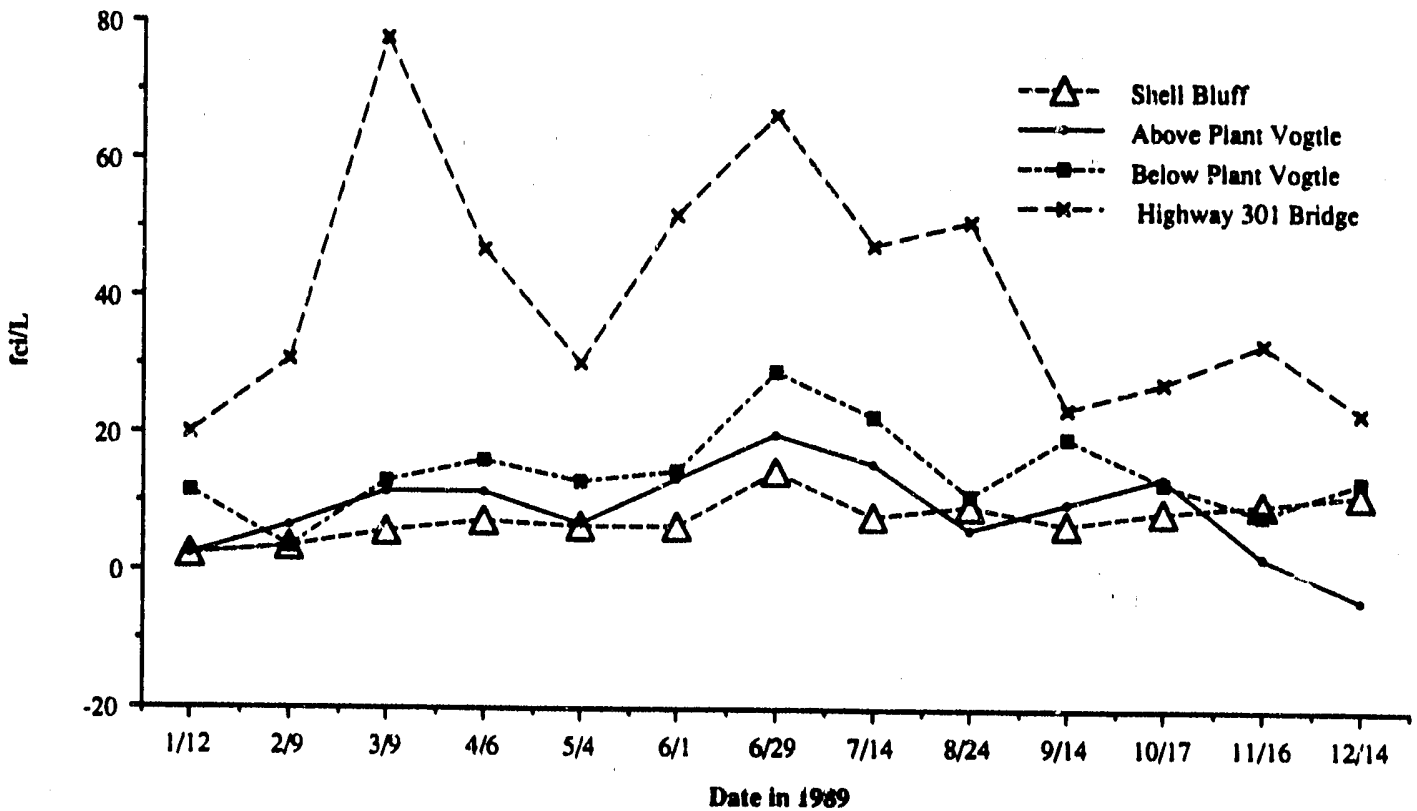

Figure 3. ${ }^{137} \mathrm{Cs}$ in the Savannah River in 1989 (Negative Values are MDAs) 
Table 4. Relative Isotopics Below Vogtle During 1989

\begin{tabular}{|c|c|c|c|c|c|c|c|c|c|c|}
\hline \multirow[t]{2}{*}{ Date } & \multirow{2}{*}{$\begin{array}{r}\text { Co.58 } \\
f(g / L \\
\end{array}$} & \multicolumn{9}{|c|}{ Lsotopics \% of Co-58 Acitivity B dow Vogtle } \\
\hline & & Cr -51 & $\mathrm{Mn}-54$ & $\mathrm{C} 0.57$ & Co-58 & Fe-59 & Co60 & $\mathrm{Nb}-95$ & $z r-95$ & Cs 137 \\
\hline $12 / 14 / 88-1 / 5 / 89$ & 3897.07 & 7.94 & 15.73 & - & 10000 & 1.29 & 5.79 & 263 & 1.15 & 0.30 \\
\hline $1 / 5-1 / 19 / 89$ & 2113.70 & - & 13.96 & 0.28 & 10000 & 0.42 & 4.45 & 1.09 & - & 0.55 \\
\hline $1 / 19-2 / 2 / 89$ & 1099.72 & 5.00 & 12.25 & - & 100,00 & 1.95 & 8.47 & 291 & 1.49 & 0.37 \\
\hline $2 / 2-2 / 16 / 89$ & 377.67 & 11.54 & 15.64 & - & 100,00 & 5.81 & 20.18 & 4.94 & 257 & 0.90 \\
\hline $2 / 16-3 / 2 / 89$ & 505.16 & - & 18.02 & - & 100.00 & - & 9.38 & - & 2.61 & 218 \\
\hline $3 / 2-3 / 16 / 89$ & 176.61 & - & 24.41 & - & 100.00 & - & 28.09 & 9.25 & 6.24 & 7.51 \\
\hline $3 / 16-3 / 30 / 89$ & 121.79 & - & 23.70 & - & 10000 & - & 30.82 & 10.89 & - & 15.05 \\
\hline $3 / 30-4 / 13 / 89$ & 98.91 . & - & 18.67 & - & 10000 & - & 13.67 & - & - & 16.44 \\
\hline $4 / 3-4 / 27 / 89$ & 82.53 & - & 43.03 & - & 10000 & - & 36.30 & 6.67 & - & 21.22 \\
\hline $4 / 27-5 / 11 / 89$ & 2937 & - & 42.33 & - & 10000 & - & 46.67 & - & - & 44.30 \\
\hline $5 / 1-5 / 25 / 89$ & 143.15 & 0.00 & 22.58 & 一 & $100 \infty$ & - & 31.64 & - & 12.93 & 16.37 \\
\hline $5 / 25-6,08 / 89$ & 246.54 & - & 32.14 & - & 10000 & - & 25.60 & 8.35 & - & 5.90 \\
\hline $6 / 08-6 / 2 / 89$ & 31.44 & - & 40.30 & - & 100,0 & - & 47.47 & 21.73 & - & 26.87 \\
\hline $6 / 22-7 / 6 / 89$ & 24.50 & - & - & - & 100.00 & - & 8459 & - & - & 119.04 \\
\hline $7 / 6-7 / 20 / 89$ & 124.14 & - & 8.32 & - & 10000 & - & 20.35 & - & - & 32,38 \\
\hline $7 / 20-8 / 3 / 89$ & 50.68 & - & 9.84 & - & 10000 & - & 16.12 & - & - & 44.46 \\
\hline $8 / 3-8 / 17 / 89$ & 171.91 & - & 20.25 & - & 10000 & - & 43.92 & - & - & 7,97 \\
\hline $8 / 17-8 / 31 / 89$ & 91.99 & - & 17.28 & - & 10000 & - & 38.67 & 8.80 & - & 12.28 \\
\hline $8 / 31-9 / 14 / 89$ & 180.23 & - & 20.47 & - & $100 \infty 0$ & - & 53.08 & 10.91 & - & 4.89 \\
\hline $9 / 14-9 / 28 / 89$ & 107.69 & - & 13.03 & - & 10000 & - & 29.03 & - & - & 18.08 \\
\hline $9 / 28-10 / 12 / 89$ & 121.87 & - & 3.67 & - & 10000 & 一 & 6.14 & - & - & 6.52 \\
\hline $10 / 12-10 / 26 / 89$ & 540.51 & - & 6.69 & - & 100.00 & - & 16.41 & - & - & 239 \\
\hline $10 / 26-11 / 09 / 89$ & 755.61 & - & 0.88 & - & 10000 & - & 5.92 & - & - & 1.05 \\
\hline $11 / 09-11 / 22 / 89$ & 42252 & - & 1.40 & - & 10000 & - & 5.04 & - & 一 & 204 \\
\hline $11 / 22-12,07 / 89$ & 299.10 & - & 6.47 & - & 10000 & - & 16.57 & 一 & - & 4.43 \\
\hline $12 / 07 \cdot 12 / 21 / 89$ & 35.59 & - & 一 & - & 100,0 & - & -28.19 & 一 & - & 37.60 \\
\hline $12 / 21 / 89-01 / 04 / 90$ & 20.40 & - & - & - & 100.00 & - & -30.46 & - & - & 50.59 \\
\hline
\end{tabular}

a) All values are relative activities on resin sample, except for ${ }^{137} \mathrm{Cs}$, which is corrected for collection efficiency. (Note: This is also true for the 1987 data of Reference 2; however, the 1988 data of Reference 3 inadvertently used the relative activity of ${ }^{137} \mathrm{Cs}$.)

startup in 1987. The sediment samples reflect many of the results observed for the river water. The underwater $\mathrm{NaI}(\mathrm{Tl})$ detector provided continuous tracking of Vogtle effluents. As in the past, all measured radionuclide concentrations are well below DOE guides for drinking water.

The Vogtle effluents continue to be dominated by ${ }^{58} \mathrm{Co}$. Furthermore, the river concentrations for ${ }^{58} \mathrm{Co}$ (see Figure 1) continued to coincide with those for ${ }^{\infty} \mathrm{Co}$ (see Figure 2). This correlation results because Plant Vogtle supplies the bulk of the ${ }^{\text {(1) }} \mathrm{Cu}$. which is illustrated by ${ }^{\infty} \mathrm{Co}$ levels $0.3 \mathrm{mi}$ above and 0.1 mi below the out all (see Table 2).

In 1989, the ${ }^{58} \mathrm{Co}$ decreased noticeably, but the decrease in ${ }^{\infty} \mathrm{C} O$ was less pronounced. Neutron activations in the coolant piping creates both of those isotopes, but ${ }^{58} \mathrm{Co}$ (71 days) builds up toward saturation and decays more rapidly than ${ }^{\circ 0} \mathrm{Co}$ (five years). Therefore, ${ }^{3 \times}$ Co reduction is more pronounced than that for "Co during processing that retains the effluents longer before discharge to the river. Both isotopes had their maximum concentrations just below Vogtle at the beginning of the year when concentrations of $3900 \mathrm{fCi} / \mathrm{L}^{38} \mathrm{Co}$ and 226 $\mathrm{fCi} / \mathrm{L}{ }^{60} \mathrm{Co}$ were measured.

Relative to ${ }^{38} \mathrm{Co}$ the river concentrations (Table 4) of most Vogtle-produced isotopes have not dramatically changed since these studies began in 1987. However, like ${ }^{\circ 0} \mathrm{Co}$ (five years), ${ }^{54} \mathrm{Mn}$ ( 313 days) has a long half-life relative to ${ }^{54} \mathrm{Co}$ ( 71 days); thus, its buildup/decay can result in increasing its relative activity, In fact from 1987 to 1989, the relative concentrations of both ${ }^{54} \mathrm{Mn}$ and ${ }^{80} \mathrm{Co}$ have increased by more than an order of magnitude. By contrast, such large variations are not seen in the relative activities of ${ }^{31} \mathrm{Cr},{ }^{34} \mathrm{Fe},{ }^{95} \mathrm{Nb}$, and ${ }^{95} \mathrm{Zr}$, which have shorter half-lives and compare better to ${ }^{88} \mathrm{Co}$. The ${ }^{37} \mathrm{Co}$ also has a relatively long half-life, but its detection was too rare for comparison.

SRS still appears to be the major source for the ${ }^{3} \mathrm{H}$ and ${ }^{137} \mathrm{Cs}$ concentrations in the river. In 1989 the average ${ }^{3} \mathrm{H}$ was 3.5 $\mathrm{pCi} / \mathrm{mL}$ at Highway $30 \mathrm{I}$ bridge (see Table 5), which agrees 
Table 5. Tritium Concentrations in 1989 (Values in $\mathrm{fCi} / \mathrm{mL})^{\circ}$

\begin{tabular}{|c|rrrrr|}
\hline \multirow{2}{*}{ Date } & \multirow{2}{*}{ Shell Bluff } & \multicolumn{3}{|c}{ Vogtle Vicinity } & \multirow{2}{*}{ Hwy 301} \\
\cline { 2 - 4 } & & $+0.3 \mathrm{mi}$ & $0.0 \mathrm{mi}$ & $-0.1 \mathrm{mi}$ & \\
\hline & & & & & \\
$1 / 26 / 89$ & $<1.3$ & $4.2 \pm 0.9$ & $4.7 \pm 0.9$ & $4.2 \pm 0.9$ & $5.8 \pm 0.9$ \\
$2 / 16 / 89$ & $<1.5$ & $2.8 \pm 1.4$ & $2.3 \pm 1.1$ & $<1.4$ & $3.9 \pm 1.1$ \\
$3 / 16 / 89$ & $<1.2$ & $<1.7$ & $<1.0$ & $<1.1$ & $3.9 \pm 1.0$ \\
$4 / 13 / 89$ & $<1.5$ & $<1.7$ & $<1.8$ & $<1.5$ & $3.0 \pm 1.0$ \\
$5 / 16 / 89$ & $<1.4$ & $<1.2$ & $<1.6$ & $<2.0$ & $3.2 \pm 0.9$ \\
$6 / 08 / 89$ & $<1.0$ & $<2.3$ & $<1.3$ & $<1.5$ & $4.6 \pm 1.0$ \\
$7 / 20 / 89$ & $<1.4$ & $<1.2$ & $1.4 \pm 1.4$ & $4.2 \pm 1.2$ & $2.1 \pm 0.6$ \\
$8 / 17 / 89$ & $<1.4$ & $1.8 \pm 0.9$ & $<1.7$ & $<1.5$ & $2.7 \pm 0.9$ \\
$9 / 28 / 89$ & $<1.5$ & $<1.1$ & $<1.1$ & $<1.0$ & $2.5 \pm 0.8$ \\
$10 / 12 / 89$ & $<1.8$ & $3.3 \pm 1.0$ & $1.9 \pm 0.9$ & $2.6 \pm 1.1$ & $3.4 \pm 1.0$ \\
$11 / 22 / 89$ & $<2.2$ & $1.9 \pm 0.9$ & $1.5 \pm 1.1$ & $3.0 \pm 1.0$ & $5.0 \pm 1.0$ \\
$12 / 21 / 89$ & $<1.5$ & $<1.1$ & $<1.7$ & $<1.5$ & $1.3 \pm 0.6$ \\
\hline
\end{tabular}

a) Errors are 2 values (other errors in report are 1-).

b) Miles are measured upstream of Vogtle outfall.

well with the $3.0 \mathrm{pCi} / \mathrm{mL}$ measured prior to Vogtle startup; ${ }^{3} \mathrm{H}$ measurements at other river locations remained at approximately $2 \mathrm{pCi} / \mathrm{mL}$, which is also comparable to prestartup values. A maximum concentration of $119 \mathrm{fCi} / \mathrm{L}^{137} \mathrm{Cs}$ was observed at Highway 301 bridge; this is comparable to the approximate $100 \mathrm{fCi} / \mathrm{L}$ average that is typically observed annually.
The ${ }^{137} \mathrm{Cs}$ concentrations near Vogtle are noticeably lower, averaging $10.1 \pm 1.2 \mathrm{fCi} / \mathrm{L}$ and $14.3 \pm 1.6 \mathrm{fCi} / \mathrm{L}$ for samples $0.3 \mathrm{mi}$ above and $0.1 \mathrm{mi}$ below the Vogtle outfall. This implies a ${ }^{137} \mathrm{Cs}$ contribution of $4.2 \pm 1.9 \mathrm{fCi} / \mathrm{L}$ from Vogtle and may signal that very small leaks in the reactor fuel are releasing trace fission products. Compared to the 1987 and 1988 yields of $1.1 \pm 1.3 \mathrm{fCi} / \mathrm{L}$ and $5.8 \pm 2.1 \mathrm{fCi} / \mathrm{L}$ respec-

Table 6. Sediment Concentrations in 1989

\begin{tabular}{|c|c|c|c|c|c|}
\hline \multirow[t]{2}{*}{ Isotope } & \multirow[t]{2}{*}{ Date } & \multicolumn{3}{|c|}{ Vogtle Vicinity" } & \multirow[t]{2}{*}{ Hwy 301} \\
\hline & & $+0.3 \mathrm{mi}$ & $0.0 \mathrm{mi}$ & $-0.1 \mathrm{mi}$ & \\
\hline${ }^{s 4} \mathrm{Mn}^{\mathrm{b}}$ & $\begin{array}{l}2 / 9 / 89 \\
7 / 13 / 89\end{array}$ & $\begin{array}{l}<4.2 \\
<4.0\end{array}$ & $\begin{array}{l}<4.3 \\
<3.4\end{array}$ & $\begin{array}{r}25.1 \pm 1.3 \\
9.9 \pm 1.2\end{array}$ & $\begin{array}{l}<4.7 \\
<6.6\end{array}$ \\
\hline${ }^{98} \mathrm{Co}$ & $\begin{array}{l}2 / 9 / 89 \\
7 / 13 / 89\end{array}$ & $\begin{array}{l}<4.3 \\
<13\end{array}$ & $\begin{array}{l}16.4 \pm 2.4 \\
18.6 \pm 5.4\end{array}$ & $\begin{array}{l}98.2 \pm 1.3 \\
17.9 \pm 2.9\end{array}$ & $\begin{array}{r}9.0 \pm 1.2 \\
<13\end{array}$ \\
\hline${ }^{60} \mathrm{Co}$ & $\begin{array}{l}2 / 9 / 89 \\
7 / 13 / 89\end{array}$ & $\begin{array}{l}<1.3 \\
<1.3\end{array}$ & $\begin{array}{l}<1.5 \\
<1.9\end{array}$ & $\begin{array}{l}6.9 \pm 0.7 \\
4.6 \pm 0.7\end{array}$ & $\begin{array}{r}2.3 \pm 0.7 \\
<1.6\end{array}$ \\
\hline${ }^{137} \mathrm{Cs}$ & $\begin{array}{l}2 / 9 / 89 \\
7 / 13 / 89\end{array}$ & $\begin{array}{l}11.5 \pm 1.5 \\
11.4 \pm 1.5\end{array}$ & $\begin{array}{l}7.5 \pm 2.0 \\
7.7 \pm 1.6\end{array}$ & $\begin{array}{l}11.4 \pm 1.0 \\
19.5 \pm 1.1\end{array}$ & $\begin{array}{l}131 \pm 2 \\
148 \pm 3\end{array}$ \\
\hline
\end{tabular}

a) Miles are measured upstream of Vogtle outfall.

b) ${ }^{4} \mathrm{Mn}$ values corrected for interference of $835.8 \mathrm{kev}$ gamma of ${ }^{22 \pi} \mathrm{Ac}$. 
Gamma Peak keV

Gamma Peak IDS
A. $\mathrm{Ra}-226$ (185), $\mathrm{Pb}-212$ (239)
B. $\mathrm{Pb}-214(295 / 352)$
C. Annihl (511)
D. Tl-208 (583), Bi-214 (609), Cs-137 (662)
E. Ac-228 (795, Co-58 (811), Mn-54 (835)
F. Ac-228 (911/964/969)
G. Bi-214 (1120)
H. K-40 (1461)
I. $\mathrm{Bi}-214$ (1764)
J. Total Nal Spectrum

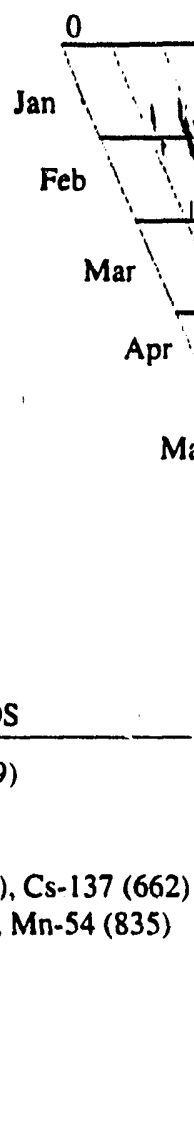

Figure 4. Results for Underwater Nal Detector at the Highway 301 Bridge

tively, the concentrations have noticeably increased. The continuation of these studies will further evaluate this trend.

The sedimen: samples contained detectable ${ }^{54} \mathrm{Mn},{ }^{58} \mathrm{Co},{ }^{60} \mathrm{Co}$, and ${ }^{137} \mathrm{Cs}$ (see Table 6). This marks the first year that ${ }^{54} \mathrm{Mn}$ was reported, because the relatively long-lived isotope has accumulated significantly in the sediment. The HPGe analysis for ${ }^{54} \mathrm{Mn}$ requires that its $834.8 \mathrm{keV}$ gamma peak be corrected for a $835.6 \mathrm{keV}$ component from background ${ }^{228} \mathrm{Ac}$. At $0.1 \mathrm{mi}$ below the Vogtle outfall, the activities of ${ }^{54} \mathrm{Mn},{ }^{58} \mathrm{Co}$. and ${ }^{6} \mathrm{Co}$ all decreased from the beginning of the year. reflecting the data of the river water samples; their respective maximum concentrations of 25,98 , and $6.9 \mathrm{fCi} / \mathrm{g}$ are the largest observed since Vogtle startup. The ${ }^{137} \mathrm{Cs}$ does not display these trends, and its values are comparable to those observed in earlier years. ${ }^{2.3}$

The underwater $\mathrm{NaI}(\mathrm{Tl})$ detector at the Highway 301 bridge continues to illustrate that Plant Vogtle effluents can be monitored per detection of the ${ }^{3 H} \mathrm{Co}$ activity. An isometric plot of count rate vs gamma energy and time is given in Figure 4, where the peak near $800 \mathrm{keV}$ is identified with the $811 \mathrm{keV}$ gamma of ${ }^{3 \mathrm{C}} \mathrm{Co}$. Figures 5 and 6 compare a time plot of this peak with a similar one for ${ }^{58} \mathrm{Co}$ concentrations measured with the resin samples. Both plots exhibit similar profiles, indicating good tracking; however, in the plot for $1987-1988^{3}$, the ratio (resin/underwater $\mathrm{NaI}$ ) of the plots was approximately two times larger than that shown in figures 5 and 6. This difference is probably due to interference effects at the lower count rates, particularly the $795 \mathrm{keV}$ and 835 $\mathrm{keV}$ gammas of ${ }^{228} \mathrm{Ac}$ and the $835 \mathrm{keV}$ of ${ }^{54} \mathrm{Mn}$ that contribute to the peak, near $800 \mathrm{keV}$. The ${ }^{228} \mathrm{Ac}$ is a natural background detected in sediment, and the long half-life of ${ }^{54} \mathrm{Mn}$ caused the build up relative to ${ }^{58} \mathrm{Co}$. For the underwater $\mathrm{NaI}(\mathrm{Tl})$ detector, the 795,811 , and $835 \mathrm{keV}$ peaks are not resolved because no resolution problem existed for the resin samples because they were counted on HPGe detectors. The underwater $\mathrm{NaI}(\mathrm{Tl})$ peak near $800 \mathrm{keV}$ in $1989 \mathrm{i}$ - comprised of ${ }^{54} \mathrm{Mn},{ }^{34} \mathrm{Co}$, and ${ }^{228} \mathrm{Ac}$; however, ${ }^{\text {9K }} \mathrm{Co}$ dominated this generally larger peak in 1987-1988. 


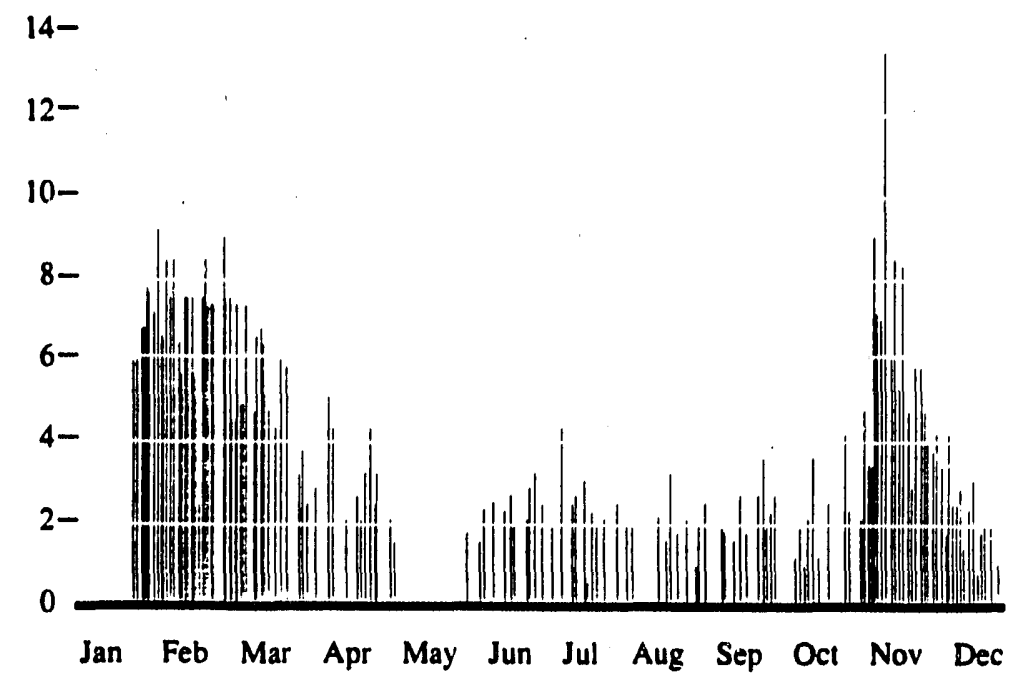

Figure 5. Results of Underwater $\mathrm{Nal}{ }^{58} \mathrm{Co}$ (1989)

Table 7 compares the maximum-detected river concentrations with the DOE guide limits for drinking water. ${ }^{4.6}$ All concentrations are well below the guide limits. Furthermore, the table illustrates that maximum concentrations in 1989 are generally lower than those of 1987 and 1988. In particular, the short-lived Vogtle-produced isotopes ${ }^{31} \mathrm{Cr}$, ${ }^{34} \mathrm{Co},{ }^{34} \mathrm{Fe},{ }^{43} \mathrm{Nb}$, and ${ }^{4} \mathrm{Zr}$ noticeably lowe,ed. The longer lived isotopes of ${ }^{3} \mathrm{H} .{ }^{34} \mathrm{Mn} .{ }^{37} \mathrm{Co}$, and ${ }^{137} \mathrm{Cs}$ concentrations correlated to those of earlier years; however, the ${ }^{54} \mathrm{Mn}$ concentration did exhibit a monotonic increase each year.

\section{Summary}

These studies have continuously monitored the Savannah River since their inception in 1986. They will continue on a routine basis, because they provide early detection of

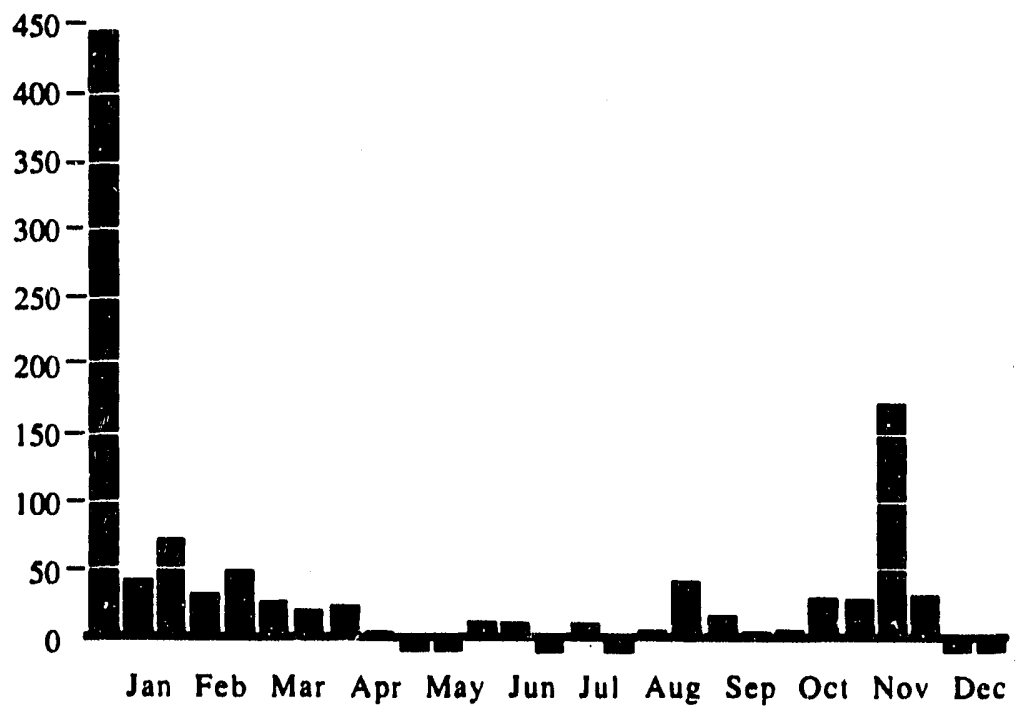

Figure 6. Results of Resin Samples for ${ }^{58} \mathrm{Co}$ at Highway 301 Bridge (1989) 
Table 7. Comparison of Maximum 1989 Levels with DOE Guides for Drinking Water (All Measured Levels are from Samples $0.1 \mathrm{mi}$. Downstream of Vogtle Outfall Unless Specified Otherwisc.)

\begin{tabular}{|c|c|c|c|c|}
\hline \multirow[b]{2}{*}{ Isotope } & \multicolumn{4}{|c|}{ Concentration ( $\mathrm{pCi} / \mathrm{L}$ ) } \\
\hline & $1987 \max$ & $1988 \max$ & 1989 max & DOE Guided \\
\hline${ }^{3} \mathrm{H}$ & $47,300^{b}$ & $4200^{\circ}$ & $5800^{\mathrm{c}}$ & $2,000,000$ \\
\hline " $\mathrm{Cr}$ & 3.70 & 2.80 & 0.30 & $11,000,000$ \\
\hline${ }^{54} \mathrm{Mn}$ & 0.06 & 0.40 & 0.61 & 50,000 \\
\hline${ }^{57} \mathrm{Co}$ & 0.02 & $0.0 \%$ & 0.01 & 100,000 \\
\hline${ }^{88} \mathrm{Co}$ & 16.8 & 15.5 & 3.90 & 40.000 \\
\hline${ }^{59} \mathrm{Fe}$ & 0.22 & 0.49 & 0.05 & 20,000 \\
\hline${ }^{\infty} \mathrm{Co}$ & 0.14 & 0.49 & 0.23 & 5,000 \\
\hline${ }^{9} \mathrm{NL}$ & 0.10 & 0.50 & 0.10 & 40.000 \\
\hline${ }^{9} \mathrm{Zr}$ & 0.17 & 0.23 & 0.04 & 60,000 \\
\hline${ }^{137} \mathrm{Cs}$ & 0.10 & $0.39^{c}$ & $0.12^{c}$ & 3,000 \\
\hline
\end{tabular}

a) DOE 5484.1 (details per reference 6).

b) Value at Vogtle outfall.

c) Value at Higt way 30: Bridge.

disturbing trends before actual health concerns evolve. The program is mutually beneficial to both Vogtle and SRS, and cooperative efforts between the two sites continue to enhance the measurements program.

\section{Acknowledgments}

Donald Hallman has continued to provide useful information on Plant Vogtle releases. C.D. Ouzts and H.T. Wilson coordinated the river sampling and analyzed the bulk of the samples.

\section{References}

1. R.A. Sigg and W.G. Winn. Pre-Operational Radio-Environmental Studies of Plant Vogtle. WSRC-RP-89-161 (May 1, 1989).
2. W.G. Winn. Radioactive Effluents in the Sarannah River -Summary Report for 1987, DPST-88-605 (June 3̈, 1988).

3. W.G. Winn. Radioactive Effluents in the Savannah River - Summary Report for 1988, DPST-88-318 (February 22. 1989).

4. Department of Energy Order DOE 5484.I (Draft 1986).

5. W.G. Winn, W.W. Bowman, and A.L. Boni. Ultra-Clean Underground Counting Facility for Low'-Level Emironmental Samples, DP-1747 (September 1987).

6. US DOE Savannah River Site Environmental Report for 1988, WSRC-RP-89-59. (1988) 

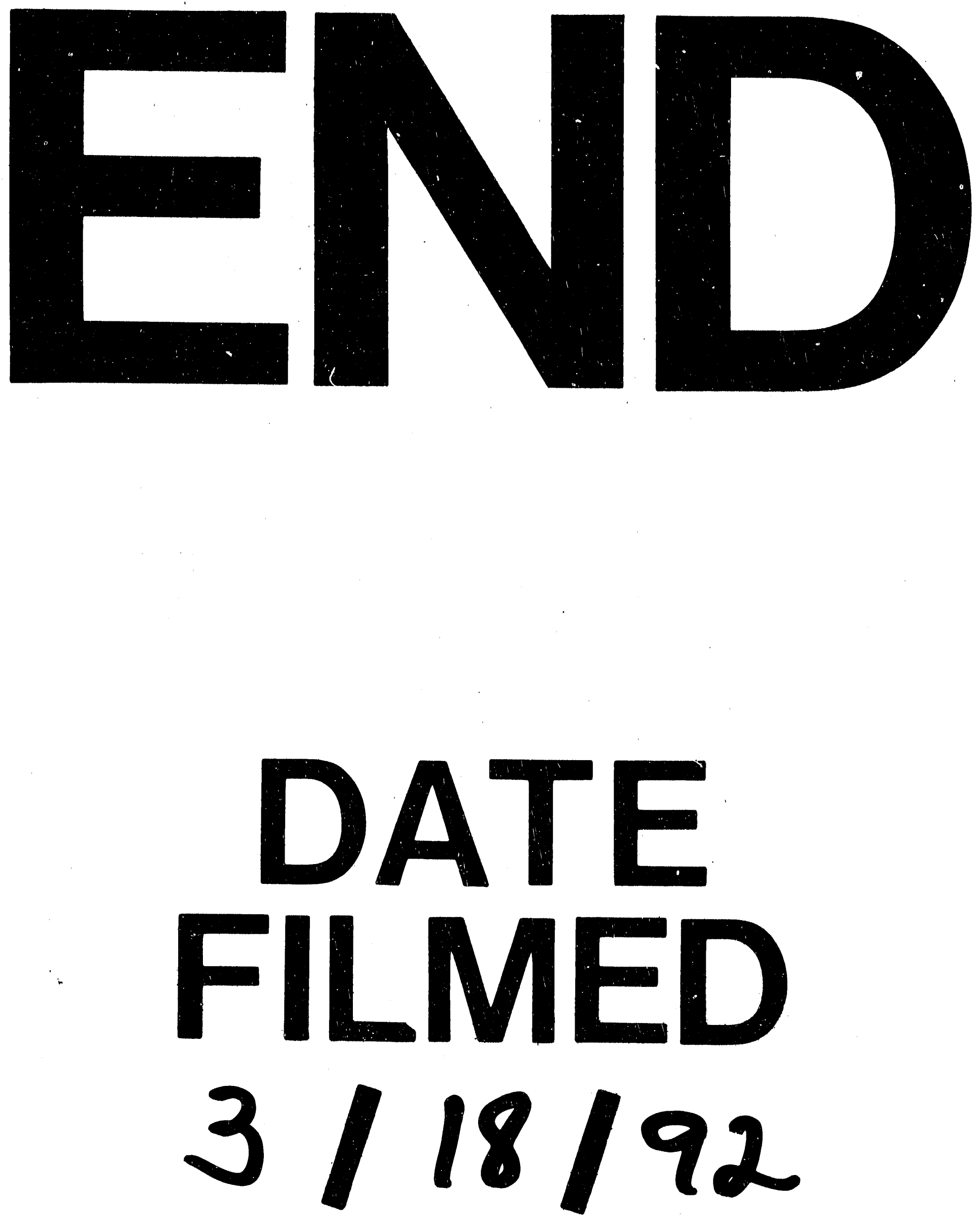
